\title{
Manfaat dan Kendala Penerapan Tutor Sebaya untuk Siswa Kelas IV Sekolah Dasar Lentera Harapan Mamit
}

\author{
Ashiong Parhehean Munthe, Henny Pradiastuti Naibaho \\ ashiong.munthe@uph.edu,pradiastutih@gmail.com \\ Fakultas Ilmu Pendidikan, Universitas Pelita Harapan, Tangerang \\ Guru Sekolah Dasar, Sekolah Lentera Harapan Nalca, Papua

\section{Benefits And Constraints Of The Implementation Of Peer Tutor For Class IV Students Primary School Lentera Harapan Mamit}

\begin{abstract}
Peer tutoring is a learning process that involves students who have high abilities to provide assistance and tutoring to students with lower abilities. There are benefits and constraints faced during the implementation of peer tutoring. This study aims to describe the benefits and constraints of the implementation of peer tutoring in fourth grade through the use of stacked short-division material. The research method used is descriptive qualitative research. The data obtained will be processed and described extensively and increasingly detailed, so that the reader will be able to comprehend the data descriptions. This research was conducted at Lentera Harapan Mamit School, Papua. The benefits of its implementation are students can express their learning difficulties directly to the tutor, students style understand the learning materials more easily because it uses the same language among fellow students. Peer tutoring also gives opportunities for students to grow together. The constraints faced are the difficulty in determining a more qualified tutor and in managing the time well because of many steps that must be applied. Preferably, while implementing peer tutoring, there should be a consideration on the selection of tutors by looking at the result of the student exercise periodically and using a timer to remind each step of the way.
\end{abstract}

Keywords: Cooperative, Facilitating Learning, Peer Tutor

Received date: 28 April 2019

\section{Article Info}

Revised date: 6 Mei 2019
Accepted date: 20 Mei 2019

\section{PENDAHULUAN}

Belajar dipandang sebagai suatu proses untuk mempersiapkan siswa pada saat ini, agar siswa mampu menghadapi dan meyelesaikan masalah dalam kehidupan masa kini dan masa mendatang. Sekolah dipersepsikan juga sebagai tempat mencari ilmu untuk membuka jendela dunia bagi siswa. Menurut Dalyono (2009: 172) bahwa bagi orang tua juga demikian, memandang sekolah sebagai tempat untuk mengembangkan kemampuan anak. Namun, ada juga pandangan yang menyatakan bahwa pendidikan adalah pengalaman belajar yang berlangsung sepanjang hayat dalam lingkungan kehidupan (Kadir, 2012: 59). Pandangan Ki Hajar Dewantara dalam Kadir (2012: 62) menguraikan bahwa pendidikan sebagai proses bagi anak untuk memaksimalkan seluruh potensinya, agar mereka sebagai insan dan anggota masyarakat, mampu mencapai "kebahagiaan" yang setinggi-tingginya. Kebahagian diartikan sebagai pencapaian kesuksesan hidup, seperti mencapai tujuan pembelajaran dan tujuan hidup setelah lulus sekolah. Untuk mencapai tujuan pendidikan yang diharapkan tersebut, maka guru harus berperan aktif dalam proses perencanaan pembelajaran yang efektif dan dapat menjawab kebutuhan belajar siswa.

Guru merupakan fasilitator dalam pembelajaran bagi siswa agar siswa yang diajar mampu memahami materi yang diajarkan. Ketika siswa belum mampu memahami materi ajar, guru harus tanggap dan kreatif untuk menyiasati permasalahan tersebut dengan mencari cara dan menerapkan metode pembelajaran yang sesuai. Merujuk pada definisi pendidikan dalam Undang-Undang Nomor 20 tahun 2003 tentang Sistem Pendidikan Nasional, pasal 1 ayat 1, bahwa pendidikan adalah usaha sadar dan terencana untuk mewujudkan suasana belajar dan proses pembelajaran agar peserta didik secara aktif mengembangkan potensi dirinya untuk memiliki kekuatan spiritual keagamaan, 
pengendalian diri, kepribadian, kecerdasan, akhlak mulia, serta keterampilan yang diperlukan dirinya, masyarakat, bangsa dan negara. Dari defenisi tersebut, ada kata-kata yang menjadi penekanan utama, yaitu pada kata "mewujudkan suasana belajar dan proses pembelajaran". Untuk mewujudkan suasana belajar dan memastikan proses pembelajaran dapat berjalan dengan baik, maka guru harus kreatif dan inovatif dalam merancang pembelajaran. Penjelasan tersebut mengindikasikan bahwa "suasana belajar dan proses pembelajaran" merupakan bagian dari tanggung jawab guru. Dengan demikian, guru harus mampu memfasilitasi siswa agar proses pembelajaran dapat berjalan sesuai tujuan.

Pada saat melaksanakan pembelajaran di kelas 4 , peneliti mengobservasi dan menemukan bahwa kelas tersebut sangat membutuhkan bimbingan, agar tujuan belajar dapat tercapai dengan baik, yaitu siswa mampu memahami materi pelajaran menghitung pembagian bagi siswa kelas 4 . Materi pembelajaran pembagian untuk kelas 1 berkisar puluhan, untuk anak kelas 2 berkisar ratusan, dan untuk anak kelas 3 sampai bilangan ribuan (Faizatin, 2012: 10). Berdasarkan hal tersebut, maka kelas 4 seharusnya sudah bisa melakukan perhitungan pembagian dengan benar melebih siswa kelas 3 .

Adanya kesulitan siswa dalam menghitung pembagian tersebut, maka peneliti menganalisis berbagai metode pembelajaran untuk diterapkan agar dapat menyelesaikan masalah tersebut. Berdasarkan hasil observasi, siswa terlihat lebih nyaman ketika berkomunikasi dengan sesama teman, karena ada kesetaraan dalam bahasa dan gaya komunikasi. Siswa juga lebih leluasa untuk bertanya tanpa ada hambatan.

Dengan konteks yang sudah dipaparkan di atas, maka peneliti memilih tutor sebaya sebagai metode pembelajaran untuk diterapkan, agar pemahaman maupun kemampuan siswa dapat meningkat. Hal ini sesuai dengan konsep tutor sebaya, yaitu siswa diberi kesempatan berdiskusi dengan teman sebaya untuk bisa membelajarkan siswa lainnya. Di samping itu, siswa lebih mudah menerima keterangan yang diberikan teman sebaya, karena ada kesetaraan bahasa dan komunikasi (Djamarah \& Zain, 2010: 25). Metode tutorial, menurut Sani (2013: 166), sangat relevan untuk kemampuan mengembangkan ide, penguasaan materi, dan belajar sangat kontekstual sesuai konteks siswa.

Konsep tutor sebaya pada intinya adalah proses pembelajaran yang melibatkan seseorang untuk memberikan bantuan dan bimbingan belajar kepada orang lain dalam kegiatan pembelajaran (Anas, 2014: 64). Metode tutor sebaya sebagai salah satu cara untuk memfasilitasi siswa belajar bersama dan dibimbing oleh teman sebaya dalam berbagi pengetahuan, saling membantu, dan dapat menciptakan keadaan yang nyaman dalam proses pembelajaran baik dalam mengungkapkan pendapat maupun bertanya ketika mengalami kesulitan.

Metode tutor sebaya merupakan salah satu bagian dari model pembelajaran kooperatif. Model pembelajaran kooperatif ini menurut Sani (2013: 131) berfungsi untuk meningkatkan kepekaan dan kesetiakawanan sosial, memudahkan peserta didik melakukan penyesuaian sosial, menghilangkan sifat mementingkan diri sendiri atau egois, meningkatkan rasa saling percaya kepada sesama, meningkatkan kemampuan memandang masalah dan situasi dari berbagai perspektif, meningkatkan kesediaan menggunakan ide orang lain yang dirasakan lebih baik, dan meningkatkan kegemaran berteman tanpa memandang perbedaan.

Mengacu pada latar belakang, maka muncul pertanyaan; apa manfaat dan kendala menerapkan metode tutor sebaya dengan materi pembagian bersusun pendek pada siswa kelas 4 di Sekolah Lentera Harapan Mamit, Papua? Tujuan dari penelitian ini adalah untuk mendeskripsikan manfaat dan kendala saat metode tutor sebaya diterapkan pada siswa kelas 4 di Sekolah Lentera Harapan Mamit, Papua.

\section{KAJIAN PUSTAKA}

Salah satu tipe pembelajaran kooperatif menurut Sani (2013: 189) adalah pembelajaran teman sejawat atau tutor sebaya. Menurut Arjanggi dan Suprihatin (2010: 94) bahwa dalam penerapan pembelajaran tutor sebaya akan membangun suasana belajar kelompok yang bersifat kooperatif bukan bersifat kompetitif. Menurut Slavin dalam Mawardi (2018: 30) juga menjelaskan bahwa pembelajaran kooperatif lebih efektif dan mempunyai dampak sosial dibandingkan pembelajaran kempetitif dan individual lainnya. Pembelajaran kooperatif adalah pembelajaran yang menugaskan siswa untuk dapat bekerja sama diantara siswa, baik dalam kelompok kecil maupun dalam kelompok besar, dengan tujuan agar siswa dapat saling membelajarkan. Menurut Sugandi (2002) dalam Kurnia, Ruskan dan Ibrahim (2014: 647) menyatakan bahwa "sistem pembelajaran cooperative learning merupakan sistem 
pengajaran yang memberi kesempatan kepada anak didik untuk bekerja sama dengan sesama siswa dalam tugas-tugas yang terstruktur".

Bekerja sama yang dimaksud dalam cooperative learning bukanlah sekedar bekerja sama, melainkan harus sesuai dengan karakteristik uniknya, yaitu; "(a) siswa bekerja dalam kelompok kooperatif untuk menguasai materi akademis; (b) Anggota-anggota dalam kelompok diatur terdiri dari siswa yang berkemampuan rendah, sedang, dan tinggi; (c) Jika memungkinkan, masing-masing anggota kelompok kooperatif berbeda suku, budaya, dan jenis kelamin; (d) Sistem penghargaan yang berorientasi kepada kelompok daripada individu" (Kurnia, Ruskan dan Ibrahim (2014: 647). Sementara menurut Amri dan Ahmadi (2010:89) dalam Syarifuddin (2011:213) menyatakan bahwa ada lima unsur dalam pembelajaran kooperatif, yaitu; (a) saling ketergantungan positif, (b) tanggung jawab perseorangan, (c) tatap muka, (d) komunikasi antar anggota, (e) evaluasi ke proses kelompok.

Kesepuluh poin yang disebut sebagai karakteristik dan unsur dalam pembelajaran kooperatif di atas, merupakan bagian penting untuk dipertimbangkan oleh guru, saat membentuk kelompok belajar siswa. Ada kemungkinan bahwa tidak semua unsur atau karakteristik tersebut bisa dipenuhi, namun hal tersebut menjadi rambu-rambu saat membentuk pembelajaran kooperatif. Keuntungan dengan adanya karakteristik dan unsur tersebut, guru menjadi lebih selektif dan terarah ketika membentuk kelompok belajar.

Salah satu tugas tanggung jawab guru adalah mampu merencanakan, mengimplementasikan dan mengevaluasi pembelajaran. Guru harus selalu memiliki sikap reflektif saat melaksanakan proses pembelajaran. Guru harus tanggap dan sigap mengatasi setiap masalah yang terjadi dalam kelas. Jika siswa tidak mampu menguasai dan atau memahami materi ajar, maka guru harus memiliki inisiatif untuk merancang ulang pembelajaran, karena belajar itu harus mencapai tujuan.

Salah satu bagian penting yang harus dimiliki guru adalah mampu memfasilitasi pembelajaran. Guru harus bisa merancang, mengelola dan menggunakan sumber belajar dengan tepat guna agar proses pembelajaran dapat berlangsung. Mengutip definisi Teknologi Pendidikan atau Educational Technology in AECT 2008 dalam Ibrahim (2015: 237) menguraikan bahwa "Educational technology is the study and ethical practice of facilitating learning and improving performance by creating, using, and managing appropriate technological processes and resources". Hal yang hendak ditekankan dari definisi tersebut adalah terkait facilitating learning. Facilitating learning bagi guru dapat diartikan sebagai upaya memfasilitasi siswa agar ada proses pembelajaran dengan melakukan desain lingkungan belajar, pengorganisasian sumber belajar, mencari metode yang sesuai, dan menyediakan alat atau media yang tepat guna dalam pembelajaran. Dengan adanya facilitating learning dari guru, maka proses pembelajaran akan dapat berjalan sesuai dengan tujuan pembelajaran.

Facilitating learning juga mendorong guru untuk melakukan refleksi berkesinambungan. Refleksi berkesinambungan adalah upaya guru dalam mengevaluasi, mengukur dan menilai diri sendiri dalam konteks pembelajaran secara terus menerus. Seluruh proses pembelajaran selalu dianalisis mulai dari perencanaan, tindakan hingga pengamatan yang utuh dalam kelas. Muara seluruh analisis selalu mengarah pada kebutuhan belajar siswa melalui capaian kompetensi yang diuraikan dalam tujuan belajar. Dalam konteks ini, analisis kebutuhan belajar siswa menjadi hal penting yang harus dilakukan oleh guru, agar proses pemfasilitasan belajar dapat berlangsung dan tepat guna.

Tutor sebaya menurut Anggorowati (2011: 104) merupakan strategi pendekatan kooperatif, yaitu model pembelajaran dalam kelompok kecil. Siswa dikelompokkan dengan tingkat kemampuan yang berbeda, agar semua anggota kelompok saling bekerja sama dan saling membantu untuk dapat memahami materi pembelajaran. Dampak lain dari pembelajaran kelompok kecil adalah mampu menciptakan situasi pembelajaran dengan saling menghargai sesama teman lainnya. Secara umum kegiatan siswa yang belajar dalam kelompok kecil akan tumbuh dan berkembang dengan pola belajar tutor sebaya (peer group) dan belajar secara bekerja sama (cooperative).

Menurut Djamarah dan Zain (2010: 25) tutor sebaya adalah metode yang dapat digunakan ketika seorang siswa lebih mudah menerima keterangan dari teman sebaya untuk melakukan suatu perbaikan dalam pembelajaran. Pengertian ini menekankan bahwa siswa dapat dan mampu saling membelajarkan satu dengan yang lainnya dan lebih mudah memahami konteks pendekatan dalam bahasa setara. Tutor sebaya menurut Sani (2013: 200) adalah kegiatan belajar yang berpusat pada peserta didik sebab anggota komunitas belajar merencanakan dan memfasilitasi kesempatan belajar untuk dirinya sendiri dan orang lain. Sementara, menurut Anas bahwa tutor sebaya merupakan suatu 
pembelajaran yang dilakukan dengan cara memperdayakan kemampuan siswa yang memiliki daya serap yang tinggi untuk membantu siswa daya serap rendah (2014: 63).

Metode tutor sebaya, menurut Schmidt dan Harriman (1998: 369), bisa efektif dengan tutor yang seusia dan berbeda usia. Pernyataan tersebut menegaskan bahwa tutor sebaya tidak harus selalu seumuran (umur yang sama), namun bisa juga dengan siswa yang berbeda usia, tetapi masih dalam konteks satu kelas yang sama. Pembelajaran kooperatif dapat dikatakan berhasil jika siswa dapat mencapai tujuan yang diharapkan melalui saling membantu (Sani, 2013: 132). Metode tutor sebaya dirancang dengan tujuan agar meningkatkan prestasi belajar siswa, membangkitkan motivasi belajar, menciptakan suasana yang disiplin serta nyaman (Anas, 2014: 66). Menurut Appulembang danTetiwar (2018: 303) metode tutor sebaya (peer tutoring) merupakan metode pembelajaran yang melibatkan setiap siswa secara aktif untuk berdiskusi, saling mengajar, dan mendengarkan arahan dari siswa yang pandai sebagai tutor dalam kelompok masing-masing.

Berdasarkan paparan teori di atas, maka dapat disimpulkan bahwa metode tutor sebaya merupakan metode yang digunakan guru untuk memfasilitasi siswa, agar terjadi proses pembelajaran dalam kelas melalui teman sebaya. Siswa yang berkemampuan daya serap tinggi, sebagai tutor, diarahkan untuk membimbing siswa yang berkemampuan daya serap rendah atau disebut dengan tutee. Tujuannya adalah agar siswa lebih memahami materi pelajaran dengan menggunakan bahasa setara. Untuk membentuk kelompok tutor sebaya, maka setiap siswa akan dibagi menjadi beberapa kelompok. Dalam kelompok yang sudah ditentukan oleh guru, siswa dapat saling bekerja sama dan saling membantu hingga setiap anggota kelompok memahami materi pembelajaran dengan baik.

Dalam landasan teori ini, penulis memaparkan beberapa teori langkah-langkah penerapan tutor sebaya. Salah satunya adalah langkah-langkah penerapan tutor sebaya menurut Anas (2014: 69-70) adalah sebagai berikut: 1) merencanakan perlakuan yang akan diterapkan oleh guru. Proses pembelajaran dengan tutorial selalu ada penjelasan ulang, baik persiapan untuk tutornya maupun saat tutor menjelsakan kepada rekan sebayanya. 2) guru menentukan tutor. Tutor dipilih dari anak yang dianggap oleh guru sangat pandai atau memiliki daya serap tinggi. Untuk menentukan tutor bisa melalui pengamatan selama proses pembelajaran dan akumulasi hasil belajar dalam priode tertentu. 3) guru melaksanakan pembelajaran dengan tutor sebaya. Tutee (siswa) bersama tutor, yang sudah ditentukan, melakukan kegiatan bersama. Tutor menjelaskan materi kepada tutee sesuai dengan arahan guru. Tutor juga bisa membantu tutee untuk menyelesaikan tugas lainnya yang diberikan oleh guru. 4) guru melakukan evaluasi. Guru memantau dan mengevaluasi proses implementasi pembelajaran secara terus menerus, agar guru menngetahui kesulitan-kesulitan yang dihadapi tutor maupun tutee. Jika salah satu tutor sudah berhasil membelajarkan tuteenya, maka tutor tersebut harus membantu tutor lainnya yang belum selesai. Tutor yang berhasil membelajarkan tuteenya, maka guru memberi pujian, hadiah sederhana atau tambahan nilai sebagai apresiasi.

Langkah-langkah penerapan tutor sebaya menurut Saminanto (2010: 48) adalah sebagai berikut: 1) guru harus memilih materi pembelajaran dan membaginya menjadi sub-sub materi. 2) guru membentuk kelompok siswa secara heterogen. Siswa yang penguasaan materinya sangat baik atau siswa yang ditunjuk sebagai tutor pada kelompok-kelompok yang sudah dibentuk. 3) saat pelaksanaan, maka masing-masing kelompok akan mempelajari materi yang akan dipandu oleh tutor (siswa yang pandai).4) guru harus memberi kesempatan kepada tutor untuk mempersiapkan materi yang ditentukan guru, baik di dalam kelas maupun di luar kelas. 5) setiap kelompok melalui wakilnya menyampaikan sub materi sesuai dengan tugas yang telah diberikan. Guru tetap sebagai narasumber. 6) guru harus meluruskan, jikalau ada siswa yang keliru konsep dan guru juga harus membuat kesimpulan dari pembelajaran tersebut.

Langkah-langkah tutor sebaya menurut Sani (2013: 201) adalah: 1). guru terlebih dahulu membentuk kelompok belajar siswa. Minimal satu kelompok beranggotakan 3 sampai 4 orang dengan beragam kemampuan. Setiap kelompok harus memiliki satu orang siswa yang memiliki kemampuan tinggi untuk dijadikan sebagai tutor. 2). tahap kedua adalah guru harus menjelaskan cara penyelesaian setiap tugas dalam kelompok dengan bimbingan tutor sebaya. Menjelaskan wewenang dan tanggung jawab setiap anggota kelompok. 3). guru menjelaskan materi pembelajaran kepada seluruh siswa sebelum diskusi dalam kelompok dan guru memberi kesempatan untuk tanya jawab apabila masih ada materi yang belum dipahami siswa. 4). guru memberi tugas kepada siswa dengan catatan khusus, bahwa siswa yang kesulitan dalam mengerjakan tugas, maka dapat meminta bimbingan kepada teman yang ditunjuk sebagai tutor. Namun, tetap dalam pantauan guru. 5). guru mengamati aktivitas belajar dan 
memberi penilaian. 6). guru, tutor, dan peserta didik memberikan evaluasi proses belajar mengajar untuk menetapkan tindak lanjut kegiatan putaran berikutnya.

Berdasarkan paparan teori di atas, maka dapat disimpulkan langkah-langkah tutor sebaya yang akan diterapkan dalam penelitian ini. Adapun langkah-langkah metode tutor sebaya yang siap diimplementasikan adalah: 1). Guru pertama harus menentukan siapa yang akan menjadi tutor dengan mengacu pada nilai akademik siswa. Nilai siswa yang selalu tinggi atau daya serap tinggi akan dijadikan sebagai tutor. 2) Untuk membagi kelompok harus disesuaikan dengan jumlah tutor yang tersedia. 3). Setelah ditentukan tutor, maka guru akan memberi arahan untuk menjelaskan tugas dan tanggung jawab masing-masing tutor. Tugas dan tanggunjawab tutor sudah ditentukan guru sebelumnya. 4). Guru memberikan pelatihan kepada tutor hingga tutor memahami materi yang akan dibagikan kepada teman sejawatnya. Pelatihan ini dilakukan di luar jam pembelajaran. Guru melatih tutor agar mampu berbagi pengetahuan kepada rekan sejawatnya sesuai materi yang akan dipelajari dalam kelompok. Guru harus menekankan pada tutor agar nereka memiliki sikap yang mau mendengar dan memotivasi rekan sejawatnya. 5). Saat penerapan pembelajaran tutor sebaya, guru harus menyampaikan tujuan pembelajaran kepada seluruh siswa secara tuntas dan jelas. 6). Guru harus memberi instruksi dan memastikan bahwa seluruh siswa sudah duduk berdasarkan kelompok yang sudah ditentukan oleh guru sebelumnya. 7). Guru menjelaskannya materi pembelajaran kepada seluruh siswa, baik tutor maupun tutee. 8) Saat guru memberikan tugas kepada tutee, maka tutor akan membantu tutee yang kesulitan mengerjakan soal-soal yang diberikan guru. 9). Guru harus berkeliling menghampiri setiap kelompok, mengamati dan membantu jika ada kelompok yang mengalami kesulitan mengerjakan soal atau materi pembelajaran. 10). Guru perlu memberikan tes individu agar mampu mengukur peningkatan pemahaman siswa terhadap materi yang sudah dipelajari. 11). Guru mengadakan evaluas bersama. Evaluasi bersama ini dilakukan oleh guru dengan tutor maupun dengan tutee. Tujuannya adalah untuk mendapatkan masukan tentang kendala yang harus diperbaiki pada pembelajaran berikutnya.

\section{METODE PENELITIAN}

Metode penelitian yang diterapkan adalah metode penelitian deskriptif. Penelitian deskriptif merupakan bagian dari penelitian kualitatif. Penelitian kualitatif menurut Raco (2010) adalah penelitian yang hasil olah datanya adalah penjabaran berupa teks yang digambarkan secara luas dan semakin lama semakin terperinci, sehingga pembaca mampu menemukan suatu makna dari hasil penelitian. Dalam penelitian kualitatif, karakteristik utama berasal dari latar belakang alami atau kenyataan alamiah di masyarakat, menggunakan metode kualitatif dengan langkah pengamatan, wawancara, dan penelaahan dokumen. Penyajian dan analisis data pada penelitian kualitatif dilakukan secara naratif (Subandi, 2011, h. 173).

Penelitian ini dilakukan bulan Agustus hingga November tahun 2017. Data dihimpun lewat wawancara terhadap guru yang mengimplementasikan tutor sebaya di kelas 4 Sekolah Lentera Harapan Mamit, Papua. Guru tersebut sekaligus sebagai observer saat melaksanakan pembelajaran. Data dari hasil observasi dan wawancara akan dianalisis untuk pemaknaan sesuai dengan tujuan penelitian, yaitu mendeskripsikan manfaat dan kendala saat diimplementasikan metode tutor sebaya pada siswa kelas 4 di Sekolah Lentera Harapan Mamit, Papua.

\section{HASIL PENELITIAN DAN PEMBAHASAN Hasil Observasi}

Berdasarkan observasi lapangan pada siswa kelas 4, metode tutor sebaya mampu memfasilitasi siswa untuk mencapai tujuan pembelajaran. Saat proses pembelajaran berlangsung, dapat dilihat, bahwa tutor mampu mendapingi dan membimbing setiap tutee yang belum memahami materi pelajaran yang diberikan guru. Tutor selalu berinisiatif mengamati cara tutee untuk memahami dan mengerjakan tugas yang diberikan guru. Tutor juga selalu menanyakan apa yang menjadi kesulitan setiap tutee, sehingga setiap tutee memiliki keberanian untuk menyampaikan kesulitannya. Setiap tutee benar-benar diarahkan dengan baik untuk mampu menyelesaikan hal-hal yang menjadi kesulitan tutee.

Proses pembelajaran tutor sebaya tidak lepas dari pengawasan guru pengajar, sehingga setiap kelompok yang memiliki kesulitan yang tidak bisa diselesaikan oleh tutor, bisa langsung bertanya kepada guru. Hal ini sesuai dengan pendapat Sani (2013: 199) bahwa proses pembelajaran tutor sebaya menuntut peserta didik untuk aktif berdiskusi dengan teman sebayanya, atau mengerjakan tugas 
kelompok dengan bimbingan atau arahan dari teman yang lebih berkompeten. Siswa yang bertugas sebagai tutor, berperan juga sebagai teman kerja. Tutor juga dilibatkan dan diberi wewenang untuk mengontrol dan memberi bantuan kepada peserta didik lain. Para tutor dilibatkan supaya hasil pembelajaran memenuhi standar yang ditetapkan. Guru harus dapat memastikan, bahwa setiap tutee mendapat arahan yang baik dari tutor untuk meningkatkan kemampuan belajar siswa.

Materi Pembagian Bersusun Pendek dengan Tutor Sebaya

Adapun materi yang digunakan dalam penerapan metode tutor sebaya, yaitu materi pembagian bersusun pendek. Berikut contoh materi pembagian bersusun pendek beserta langkah yang perlu diperhatikan. Materi ini diimplementasikan saat menerapkan tutor sebaya. Contoh soal adalah 450:3, maka cara penyelesainnya adalah seperti dalam tabel 1 berikut ini:

Tabel 1. Ilustrasi dan penjelasan penyelesaian contoh pembagian bersusun pendek

\begin{tabular}{|c|c|}
\hline Ilustrasi & Penjelasan \\
\hline 50 & $\begin{array}{l}\text { Hal pertama yang harus dilakukan adalah } 4 \text { dibagi } 3 \text {. Hasil } 4: 3 \text { diletakkan di } \\
\text { atas garis porogapitnya. Hasil dari } 4: 3 \text { adalah } 1 \text {, karena tidak ada nilai yang } \\
\text { dikali } 3 \text { nilainya } 4 \text {. Oleh karena itu harus dicari perkalian yang mendekati } 4 \\
\text { namun tidak boleh lebih besar dari angka } 4 \text {. Sehingga nilai yang paling } \\
\text { mendekati adalah } 1 \text {. }\end{array}$ \\
\hline dikali & $\begin{array}{l}\text { Ilustrasi disamping dapat dilihat bahwa hasil 1x } 3 \text { adalah } 3 \text { lalu diletakkan di } \\
\text { bawah angka } 4 .\end{array}$ \\
\hline & $\begin{array}{l}\text { Setelah melakukan perkalian } 1 \text { x } 3 \text { yang diletakkan di bawah angka } 4 \text {, maka } \\
\text { kemudian } 4 \text { dikurangi dengan hasil perkalian, yaitu } 3 \text {. }\end{array}$ \\
\hline & $\begin{array}{l}\text { Hasil dari pengurangan 4-3 adalah } 1 \text { yang diletakkan di bawah garis } \\
\text { pembatas pengurangannya. }\end{array}$ \\
\hline & $\begin{array}{l}\text { Langkah selanjutnya yang harus dilakukan adalah dengan menurunkan nilai } \\
\text { yang ada dibelakang } 4 \text {, yaitu } 5 \text {. Hal ini dilakukan karena } 1 \text { dibagi } 3 \text { tidak bisa. }\end{array}$ \\
\hline $\begin{array}{l}\frac{1}{450}=\frac{15}{450} \\
\frac{3}{15}=\frac{3}{15}\end{array}$ & $\begin{array}{l}\text { Setelah menurunkan angka } 5 \text {, maka hasilnya adalah } 15 \text {. Angka } 15 \text { inilah yang } \\
\text { dibagi dengan } 3 \text {. Hasil pembagian diletakkan di atas garis dengan diletakkan } \\
\text { di belakang } 1 \text {. }\end{array}$ \\
\hline$=\begin{array}{l}\frac{15}{450} \\
\frac{3}{15}\end{array}-\frac{3 \longdiv { 4 5 0 }}{15}=$ & $\begin{array}{l}\text { Kemudian hasil } 15 \text { dibagi dengan } 3 \text {, maka hasilnya adalah } 5 \text {. Angaka } 5 \\
\text { tersebut, kemudian dikalikan dengan } 3 \text { lagi, maka hasilnya } 15 .\end{array}$ \\
\hline $\begin{array}{l}\frac{15}{450}=\frac{150}{3}=\frac{350}{15} \\
\frac{3}{15}=\frac{15}{\theta}= \\
\frac{15}{\theta}=\frac{3}{15}=\end{array}$ & $\begin{array}{l}\text { Jika hasilnya } 0 \text {, maka sudah selesai. Namun, jika belum sampai nilai nol, } \\
\text { maka perlu untuk melakukan perhitungan dengan mengulang seperti } \\
\text { langkah-langkah bersusun sebelumnya. Seperti yang terdapat pada contoh di } \\
\text { samping, ternyata hasilnya nol setelah } 15-15 \text {, maka angka } 0 \text { tersebut tinggal } \\
\text { diletakkan saja di belakang angka 5, sehingga nilai di atas menjadi } 450 \text {. } \\
\text { Angka di atas adalah hasil pembagian } 450: 3 \text { yang hasilnya adalah } \\
\text { 150.Artinya perhitungan sudah selesai. }\end{array}$ \\
\hline
\end{tabular}

Sumber Ilustrasi: https://bidangstudi.com/354/cara-pembagian-bersusun-porogapit-ribuan.html, Situs Pendidikan Mata Pelajaran Online

Melihat langkah-langkah pengerjaan pembagian bersusun pendek di atas, maka langkah yang perlu selalu diperhatikan adalah dibagi, dikali, dan dikurang. Setelah selesai pengurangan, maka akan dilanjutkan kembali ke langkah awal, yaitu dibagi, dikali dan dikurang. Melakukan perhitungan dalam 
pembagian bersusun pendek, setiap langkah hanya diulang-ulang hingga hasilnya nol (0). Ini menjadi bagian penting yang harus diingat oleh siswa, terutama tutor sebagai pembimbing.

Soal-soal seperti di atas adalah materi yang harus dikuasai oleh tutor terlebih dahulu agar dapat membimbing teman sebaya dalam kelompoknya. Para tutor harus membimbing temannya untuk melakukan perhitungan pembagian sesuai dengan langkah yang telah diajarkan. Dalam membimbing pun, para tutor selalu diingatkan untuk tidak memberikan hasil jawaban, tetapi harus mengajarkan cara kerjanya. Tutor juga harus aktif memperhatikan teman sebayanya yang masih mengalami kesulitan.

\section{Hasil Wawancara}

Berdasarkan hasil wawancara dengan guru pengajar, bahwa pelaksanaan tutor sebaya diawali dengan merancang pembelajaran. Sebelum memasuki kegiatan pembelajaran, guru memanggil 4 tutor yang sudah di pilih sebelumnya. Sesuai langkah-langkah penerapan tutor sebaya, guru menentukan tutor berdasarkan nilai akademik siswa. Nilai siswa yang selalu tinggi atau daya serap tinggi akan dijadikan sebagai tutor. Pembagian kelompok disesuaikan dengan banyaknya tutor yang tersedia. Tutor diberi arahan terlebih dahulu sebelum pelaksanaan dimulai. Arahan yang diberikan guru adalah mengenai halhal yang akan dilakukan pada saat diskusi kelompok nantinya. Tutor juga diberi pelatihan berupa 1 soal dengan penekanan pada cara dan hal-hal yang perlu dilakukan saat perhitungan pembagian bersusun pendek. Tujuannya adalah untuk lebih mepersiapkan tutor dalam memahami materi, sehingga saat proses tutor sebaya berlangsung dapat berjalan dengan baik. Selanjutnya, guru memulai kegiatan pembelajaran sesuai dengan apa yang telah direncanakan dalam Rencana Pelaksanaan Pembelajaran.

Pada awal kegiatan pembelajaran, siswa diarahkan untuk mengingat atau mengulang secara singkat pembelajaran sebelumnya. Setelah itu, lalu dijelaskan tujuan pembelajaran yang akan dicapai dalam pembelajaran ini. Guru juga menjelaskan kepada siswa bahwa akan dilaksanakan pembelajran dengan tutor sebaya. Sebelumnya guru sudah menulis pembagian kelompok di papan tulis. Siswa diarahkan untuk duduk sesuai dengan kelompoknya masing-masing dan pada setiap kelompok sudah ada tutor di dalamnya. Siswa dapat mengikuti instruksi guru dengan baik, tenang dan tanpa ada suara ataupun pertanyaan. Sebelum memulai diskusi, guru menjelaskan terlebih dahulu materi yang akan dibahas dalam kelompok. Guru menjelaskan materi melalui tanya jawab dengan siswa untuk membahas beberapa contoh soal.

Setelah guru selesai menjelaskan materi pelajaran lewat diskusi dan tanya jawab, maka guru menulis soal di papan tulis yang nantinya akan dikerjakan dalam kelompok. Soal tersebut merupakan bahan ajar yang harus dipelajari oleh siswa. Siswa dipersilahkan untuk mengerjakan soal tersebut bersama kelompk. Saat diskusi dalam kelompok, siswa dipersilahkan untuk menggunakan bahasa daerah atau bahasa yang memudahkan mereka untuk bisa belajar. Kegiatan belajar kelompok tersebut selalu dipandu dan diarahkan oleh tutor untuk membimbing setiap tutee dalam mengerjakan setiap soalsoal yang ada. Setiap tutee yang masih bingung bisa bertanya secara langsung kepada tutor, tanpa harus menunggu giliran. Selama proses tutor sebaya berlangsung, guru berkeliling melihat bagiamana siswa belajar bersama kelompok dan bagaiman peran tutor di dalam kelompok.

Ternyata, dengan penerapan tutor sebaya ini, siswa terlihat lebih mudah dan leluasa bertanya tanpa ada rasa taku. Mereka saling bertukar pikiran, saling memberi masukan, dan tutor berperan menjelaskan bagaimana cara perhitungan yang benar. Ada juga tutor yang masih bertanya kepada guru, namun hanya sebatas memastikan langkah yang akan dilakukan dalam perhitungan. Setiap kelompok terlihat sangat antusias ketika bisa belajar bersama teman dalam kelompok dan semua anggota kelompok sangat aktif mengerjakan setiap soal.

Setelah siswa selesai mengerjakan soal, siswa diberi instruksi untuk kembali duduk ke temapt masing-masing. Sebelum siswa diberikan kembali lembar soal untuk dikerjakan secara individu, guru bertanya bagaimana perasaan mereka setelah belajar bersama kelompok. Ternyata banyak yang merasa lebih mudah memahami materi pelajaran saat diskusi dalam kelompok. Hal ini pun membangkitkan semangat siswa untuk mengerjakan soal tes kembali secara individu. Bekerja bersama kelompok membuat siswa semakin percaya diri untuk bisa mengerjakan setiap soal tes yang akan dibagikan.

Guru mulai membagikan setiap lembar tes kepada masing-masing siswa. Siswa diberikan waktu 45 menit untuk mengerjakan soal tes tersebut. Selama siswa mengerjakan soal tes, guru berkeliling untuk memastikan bahwa setiap siswa tidak melakukan kecurangan dalam mengerjakan soal. Setiap siswa yang telah selesai mengerjakan tes, dipersilahkan untuk mengumpulkan di meja guru dan kembali duduk rapih sambil menunggu teman yang belum selesai. Guru memastikan semua siswa telah selesai, lalu pembelajaran di akhiri dengan evaluasi bersama-sama. Setiap siswa diberi kesempatan memberikan 
pendapat mengenai pembelajaran hari ini. Banyak siswa yang menyatakan bahwa diri mereka senang dan merasa lebih mudah saat bisa belajar serta berdiskusi dengan teman. Hal tersebut sangat membantu mereka ketika mengerjakan soal tes yang diberikan, mereka menjadi lebih mengerti dalam melakukan proses perhitungan pembagian bersusun pendek.

\section{Manfaat dan Kendala Saat Menerapkan Tutor Sebaya Manfaat Tutor Sebaya}

Berdasarkan hasil wawancara dengan guru dan hasil observasi saat implementasi tutor sebaya di kelas 4 dengan materi Pembagian Bersusun Pendek, maka peneliti menyusun beberapa manfaat yang didapatkan dari penerapan tutor sebaya tersebut. Adapun manfaat yang diperoleh melalui penelitian ini adalah sebagai berikut, yaitu: 1). Setiap siswa bisa mengungkapkan apa yang menjadi kesulitan belajarnya langsung kepada tutor tanpa harus malu atau takut, karena ada perbedaan otoritas dengan guru. Di dalam kelompok, siswa juga dapat saling berdiskusi untuk memberikan pendapat dari masingmasing yang di fasilitasi oleh tutor sebaya. 2) Dengan adanya tutor sebaya, siswa dapat belajar untuk saling memahami tentang sifat atau karakter satu siswa dengan siswa lainnya yang ada dalam kelompok. 3). Siswa lebih mudah memahami materi pembelajaran, karena menggunakan bahasa setara yang mempermudah siswa untuk mengerti. 4). Siswa yang berperan sebagai tutor, belajar menjadi pemimpin dan membimbing teman sebaya untuk berdiskusi dalam kelompok. 5). Siswa memiliki keleluasaan untuk mengutarakan ide dan pendapat, tanpa harus bergantung penuh pada tutor. Tutor hanya berperan sebagai fasilitator, agar diskusi dapat berjalan sesuai dengan tujuan. 6). Siswa yang berperan sebagai tutor, akhirnya mampu mengambil keputusan sendiri, jika terjadi perbedaan pendapat diantara siswa. 7). Suasana pembelajaran menjadi sangat santai dan nyaman, karena siswa dapat berkomunikasi dengan teman sebaya tanpa ada batasan otoritas seperti guru dengan siswa.

Hasil penelitian di atas sangat selaras dengan paparan Briggs (2013) bahwa manfaat dari pembelajaran tutor sebaya adalah ada semangat untuk saling membangun tim, kenyaman secara psikologis karena berhadapan dengan rekan sejawat, dapat meningkatkan kompetensi sosial, keterampilan komunikasi, siswa lebih percaya diri, interaksi langsung antar siswa akan mendorong pembelajaran yang aktif, dan mampu meningkatkan hasil pembelajaran. Demikian juga dari hasil penelitian yang dilakukan oleh Tetiwar dan Appulembang (2018: 307) memperkuat pernyataan, bahwa penerapan tutor sebaya (peer tutoring) bermanfaat untuk meningkatkan pemahaman konsep materi perkalian bersusun pendek pada siswa kelas III B. Demikian juga hasil penelitian yang dilakukan oleh Rezeki (2017: 898) disimpulkan bahwa pembelajaran model tutor sebaya (peer tutoring) bermanfaat untuk meningkatkan hasil belajar Matematika Siswa kelas III. Menurut Hendriansyah, Milyartini, Kurdita (2013: 2) bahwa metode pembelajaran tutor sebaya juga dapat meminimalisir dominasi guru dalam pembelajaran dan guru berperan sebagai fasilitator untuk meningkatan keterampilan dan kemampuan belajar siswa.

\section{Kendala Saat Menerapkan Tutor Sebaya}

Meskipun ada manfaat yang diperoleh dari penerapan metode pembelajarana tutor sebaya, namun tidak ada metode pembelajaran yang sempurna dan bebas dari segala kekurangan. Demikian halnya dengan penerapan metode tutor sebaya. Pasti ada kendala yang dihadapi, meskipun kendala tersebut tidak terlalu mengganggu proses pembelajaran secara utuh. Beberapa kendala yang dihadapi guru saat menerapkan metode tutor sebaya, yaitu: 1). Sulit untuk menentukan tutor yang berpatokan pada nilai tes sebelum tindakan, karena nilai siswa sering naik turun, sehingga membutuhkan masukan di luar nilai-nilai yang sudah sebagai bahan pertimbangan. Misalnya: siswa A yang ditunjuk sebagai tutor, ternyata mendapatkan nilai tes pertama rendah di bawah Kriteria Ketuntasan Minimal (KKM), namun pada tes kedua siswa mendapatkan nilai di atas KKM. Dengan demikian, untuk mengambil keputusan siapa yang menjadi tutor, maka perlu meminta masukan dan pertimbangan dari guru lainnya. Serta dapat juga mempertimbangkan dari nilai latihan atau tugas-tugas lainnya saat proses pembelajaran berlangsung. 2). Siswa yang memiliki kemampuan akademik tinggi, tidak otomatis menjadi tutor, karena harus mempertimbangkan kemampuan membimbingn dan memimpin siswa-siwa lainnya untuk bisa memfasilitasi proses pembelajar dan berdiskusi dapat berjalan dengan baik. 3). Sulit untuk mengelola waktu dengan baik, karena banyak langkah yang harus diterapkan. Misalnya: pada langkah ketiga yang sudah dipilih diimplementasikan dalam penerapan tutor sebaya, yaitu memberikan pelatihan kepada tutor. Pada langkah ini, harus dijelaskan lebih banyak materi kepada tutor, sehingga membutuhkan waktu yang lebih lama. Perlu memastikan setiap tutor sudah memahami materi yang akan didiskusikan dalam kelompoknya masing-masing. 
Manfaat dan Kendala Penerapan Tutor Sebaya untuk Siswa Kelas IV Sekolah Dasar Lentera Harapan Mamit (Ashiong Parhehean Munthe, Henny Pradiastuti Naibaho)

Hasil temuan tentang kendala penerapan tutor sebaya tersebut, sangat relevan seperti yang dipaparkan oleh Lopez, Purba, dan Indriani (2016: 90), yaitu saat mempelajari materi pelajaran yang sulit, maka pelatihan tutorial bagi para tutor harus dilakukan secara intens. Dengan demikian, guru harus siap dan rela menyediakan waktu lebih untuk melatih tutor. Disamping itu, perlu ada penambahan cakupan materi pelajaran yang akan dipelajari dalam kelompok, agar kegiatan tutorial dapat berjalan lebih interaktif dan efektif. Demikian juga yang dipaparkan oleh Djamarah (2010, hlm.26-27) bahwa kekurangan dari penerapan tutor sebaya diantaranya: siswa yang dibantu (tutee) merasa hanya berhadapan dengan tema sendiri (tutor), sehingga kurang serius dalam belajar. Sementara, bagi guru, saat menerapkan tutor sebaya kesulitan untuk menentukan tutor yang tepat untuk masing-masing kelompok.

\section{SIMPULAN DAN SARAN}

Penerapan metode tutor sebaya merupakan metode yang mampu memfasilitasi siswa dan memberikan kesempatan kepada siswa dalam mengembangkan kemampuannya bersama teman sebayanya yang juga adalah tutornya. Metode ini mampu membawa siswa kepada proses pembelajaran yang nyaman, karena siswa mampu mengungkapkan pendapatnya ataupun kesulitannya tanpa ada rasa ragu ataupun malu. Metode tutor sebaya juga dapat mengajarkan kepada siswa untuk bisa saling berbagi dan saling menolong teman yang masih kesulitan memahami materi pelajaran. Hal ini membuat penyampaian materi lebih efesien untuk meningkatkan kemampuan siswa memahami materi pembagian bersusun pendek. Walaupun ada kendala, namun dibalik setiap kendala yang terjadi, banyak dari setiap siswa yang sangat menikmati proses pembelajaran dengan tutor sebaya.

Apabila hendak menerapkan metode tutor sebaya, ada baiknya mempertimbangkan beberapa saran berikut ini, yaitu: a) pemilihan tutor dapat dilakukan dengan melihat nilai latihan-latihan kesehariannya dan meminta masukan dari guru lainnya sebagai alternatif pertimbangan. b). supaya dapat berjalan sesuai rencana, alangkah baiknya setiap langkah diukur waktunya. Hal ini bisa disisasati dengan menggunakan timer untuk memberi pengingat batasan waktu disetiap langkah yang diterapkan. c) guru harus mempersipakan waktu yang cukup agar mampu mempersiapkan tutor melalui bimbingan tutorial dengan baik, sehingga tutor yang ditunjuk tuntas memahami materi yang akan ditutorkan kepada siswa lainnya.

\section{DAFTAR PUSTAKA}

Anas, M. 2014. Mengenal Metode Pembelajaran. Pasuruan: CV. Pustaka Hulwa.

Anggorowati, N. P. 2011. Penerapan Model Pembelajaran Tutor Sebaya Pada Mata Pelajaran Sosiologi, dalam Jurnal Komunitas 3(1), 103-120. Retrieved from http://journal.unnes.ac.id/nju/index.php/komunitas

Arjanggi, R., Suprihatin, T. 2010. Metode Pembelajaran Tutor Teman Sebaya Meningkatkan Hasil Belajar Berdasar Regulasi-Diri, dalam Makara, Sosial Humaniora, 14(2), 91-97. Retrieved from http://hubsasia.ui.ac.id/old/index.php/hubsasia/article/view/666/53

Briggs, S. 2013. How Peer Teaching Improves Student Learning and 10 Ways To Encourage It. Retrieved from, https://www.opencolleges.edu.au/informed/features/peer-teaching/

Dalyono, M. 2009. Psikologi Pendidikan. Jakarta: Rineka Cipta.

Darmadi, H. 2017. Pengembangan Model-metode Pembelajaran dalam Dinamika Belajar Siswa. Yogyakarta: Deepublish.

Djamarah, S. B., Zain, A. 2010. Strategi Belajar Mengajar. Jakarta: PT. Rineka Cipta.

Faizatin, N. 2012. Belajar Mengenal Aritmatika. Jakarta: PT. Balai Pustaka.

Guru Online, Cara Pembagian Bersusun Porogapit Puluhan Ratusan Ribuan, Retrieved from https://bidangstudi.com/354/cara-pembagian-bersusun-porogapit-ribuan.html

Harriman, N. E, \& Schmidt, M. W. 1998. Teaching Strategies for Inclusive Classrooms. USA: Harcourt Brace College. 
Hendriansyah, D., Milyartini, R., Kurdita, E. 2013. Penerapan Metode Pembelajaran Tutor Sebaya dalam Meningkatkan Keterampilan Bermain Ornamen Suling Lubang Enam (Penelitian Tindakan Kelas di SMP Negeri 4 Subang), dalam Jurnal Antologi Departemen Pendidikan Seni Musik FPSD UPI, 1(3), 1-17. Retrieved from http://ejournal.upi.edu/index.php/antomusik/article/view/237

Ibrahim, A. A. 2015. Evolutionary Nature of the Definition of Educational Technology, dalam International Journal of Social Sciences and Education, 5(2), 233-239. Retrieved from http://ijsse.com/sites/default/files/issues/2015/v5i2/Paper-6.pdf

Kadir, A. 2012. Dasar-Dasar Pendidikan. Jakarta: Kencana Prenada Media Group.

Kurnia, Ruskan dan Ibrahim. 2014. Pengembangan Model Pembelajaran Berbasis Cooperative Learning dalam Meningkatkan Motivasi Belajar Mahasiswa dan Peningkatan Mutu Lulusan Alumni Fasilkom UNSRI berbasis E-Learning (studi kasus: matakuliah pemrograman web), dalam Jurnal Sistem Informasi,6(1), 645-654. Retrieved from http://ejournal.unsri.ac.id/index.php/jsi/index

Lopez, M. C., Purba, Z. M., Indriani S. 2016. Penerapan Metode Tutor Sebaya dalam Meningkatkan Hasil Belajar Kognitif Siswa Kelas XI SMA ABC Yogyakarta pada Topik Sistem Gerak, dalam Polyglot: Jurnal Ilmiah, 12(2), 70-91.

Mawardi. 2018. Merancang Model dan Media Pembelajaran, dalam Scholaria Jurnal Pendidikan dan $\begin{array}{lllll}\text { Kebudayaan, } & 8 & (1), & \text { 26-40. } & \text { Retrieved }\end{array}$ http://ejournal.uksw.edu/scholaria/article/view/1412/791

Raco, J.R. 2010. Metode Penelitian Kualitatif: Jenis, Karakteristik, dan Keunggulannya. Jakarta: Grasindo.

Rezeki, P. S. 2017. Peningkatan Hasil Belajar Matematika Melalui Modeltutor Sebaya (Peer Tutor) Kelas III, dalam Jurnal Pendidikan Guru Sekolah Dasar, 9(6), 894-899.

Saminanto. 2010. Ayo Praktik PTK. Semarang: RaSAIL Media Group.

Sani, R. A. 2013. Inovasi Pembelajaran. Jakarta: Bumi Aksara.

Subandi. 2011. Deskripsi Kualitatif Sebagai Satu Metode dalam Penelitian Pertunjukan, dalam Harmonia: Journal of Arts Research and Education, 11 (2), 173-179. Retrieved from https://journal.unnes.ac.id/nju/index.php/harmonia/article/view/2210, https://doi.org/10.15294/harmonia.v11i2.2210

Syarifuddin, A. 2011. Model Pembelajaran Cooperative Learning tipe Jigsaw dalam Pembelajaran, dalam Ta'dib, Jurnal Pendidikan Islam, 16(02), 210-226. Retrieved from http://jurnal.radenfatah.ac.id/index.php/tadib/article/view/61

Tetiwar, J., Appulembang, O. D. 2018. Penerapan Metode Peer Tutoring untuk Meningkatkan Pemahaman Konsep Materi Perkalian Bersusun Pada Siswa Kelas III SD, dalam Scholaria Jurnal Pendidikan dan Kebudayaan, 8(3), 302-308. Retrieved from http://ejournal.uksw.edu/scholaria/article/view/1818 